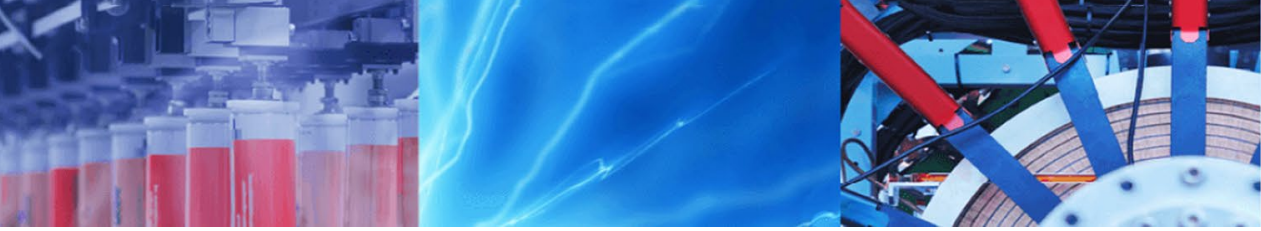

Research Article

\title{
Spatial and temporal distribution in the biochemical composition of sedimentary organic matter in a tropical estuary along the west coast of India
}

\author{
Jose Mathew ${ }^{1} \cdot$ Anu Gopinath ${ }^{2} \cdot$ G. D. Martin ${ }^{2}$
}

() Springer Nature Switzerland AG 2019

\begin{abstract}
Distribution of sedimentary organic matter was undertaken in Cochin estuary, the second largest wetland ecosystem in India. Surface sediment samples were collected from twenty-seven stations during 2016 constituting the pre- and post-monsoon periods. The sediment samples were analysed for labile fractions of biochemical constituents such as carbohydrates (CHO), proteins (PRT) and lipids (LPD). Irrespective of the sampling periods, proteins $(71 \%, 38 \%)$ constitute the major labile fraction, followed by carbohydrate $(23 \%, 36 \%)$ and finally lipids $(5 \%, 24)$. The application of biochemical index using PRT:CHO ratio revealed the presence of freshly deposited as well as the presence of aged organic matter in the estuary. The LPD:CHO ratio revealed low nutritional quality of sedimentary organic matter during the pre-monsoon and enhanced quality in post-monsoon. The trophic state classification based on biopolymeric carbon (BPC), PRT and CHO values unveils the fact that estuarine sediment nature varied between mesotrophic, eutrophic and meso-oligotrophic status. Low BPC:TOC ratios were observed pointing less availability of food to benthic source, and the organic matter present was mainly refractory in nature.
\end{abstract}

Keywords Proteins · Carbohydrates · Lipids · Biopolymeric carbon · TOC:TN ratio · Cochin estuary

\section{Introduction}

Estuaries are considered to be versatile and most productive aquatic ecosystems sustaining rich bioresources, and estuarine sediments act as preferential sites for particles which are either of marine or terrestrial origin $[8,45]$. The autochthonous biological production is considered to be the major source of organic materials to the sediments [11]. However, in anthropogenised estuaries waste inputs may significantly affect the quality and quantity of organic materials incoming to sediments $[11,28]$. Depending upon the water column chemistry either due to physical, chemical or biological processes, considerable amount of organic matter may sink and gets preserved in sediments [32], and after sedimentation, they are continuously subjected to degradation and mixing; simultaneously, deposition of other materials is continued [10]. Thus, the organic matter present in aquatic niches can be regarded as mixture of allochthonous and autochthonous sources which originates from primary production by intrinsic aquatic plants, contributions from tidal transportations, land use changes, agricultural runoff and industrial and municipal wastes $[39,76,78]$

The reliability in estimating biochemical composition of sediments (involves measurement of carbohydrates, proteins and lipids) to unravel the origin of particles and the factors controlling their diagenesis are well established $[10,11]$. The assemblage of biochemical constituents to assess the quality of organic materials as available food to benthic consumers and to interpret the trophic status of marine ecosystems has gained wide acceptance $[9,12$, $16,17,20,29,46,52,59]$. Hence, estimation of biochemical parameters represents ideas regarding biogeochemical

$\triangle$ Jose Mathew, josemathew07@gmail.com | ${ }^{1}$ Department of Chemistry, St Albert's College, Ernakulam, Kerala, India. ${ }^{2}$ Kerala University of Fisheries and Ocean Studies, Kochi, Kerala, India.

SN Applied Sciences (2019) 1:150 | https://doi.org/10.1007/s42452-018-0128-2

Received: 31 July 2018 / Accepted: 14 December 2018 / Published online: 4 January 2019

SN Applied Sciences

A SPRINGER NATURE journal 
characterisation of sedimentary environments in estuaries $[53,54,73]$.

Cochin estuary (also called Vembanad Lake) is the second largest wetland ecosystem in India which nurtures diverse types of flora and fauna. But human-induced pressures in the form of industrial effluents, land reclamation, harbour expansion development, dredging activities and urbanisation have altered the face of the estuary $[27,47]$. Nutrient enrichment, sewage and domestic inputs, marine fish farming $[2,41,42,55]$ are the major anthropogenic factors influencing this estuary. Studies conducted pertaining to organic matter in estuary are few and sparsely reviewed $[26,57,62]$. The present study aims to assess the biochemical composition in sediments as well as to unveil the benthic trophic status through indexes both spatially and temporally. This could provide an insight of dynamic patterns of organic matter distribution occurring in the estuary.

\section{Materials and methods}

\subsection{Description of the study area}

The Cochin estuary (Lat $9^{\circ} 30^{\prime}-10^{\circ} 10^{\prime} \mathrm{N}$ and Lon $76^{\circ} 15^{\prime}-76^{\circ} 25^{\prime}$ E) extends between the cities of Azhikode in the north and Allepey in the south. Freshwater supply to the estuary is fed by six rivers, namely Pamba, Achankovil, Manimala, Meenaachil, Periyar and Muvattupuzha along with their tributaries and several water channels. Among these, Periyar in the northern arm and Muvattupuzha in the southern arm discharge freshwater directly to the estuary, and hence, there was a vibrant effect on prevailing salinity of the Cochin estuary. Around $>60 \%$ of freshwater is received by the estuary during summer monsoon (June-September) and $10-25 \%$ in the winter monsoon (November-December) $[36,67]$. The northern arm of the estuary is highly subjected to anthropogenic interventions owing to several industries, and the river is considered to be cess pool of toxins $[2,36,63,64]$. The southern limb constituting fewer industries on the bank of River Chitrapuzha (situated on the lower part of Cochin estuary) upon bringing freshwater also adds considerable amount of pollutants to the estuary. Besides, Muvattupuzha River constituting pollution in the form of agricultural practices, coconut husk retting centres, fish processing plants, wastes from sewage and domestic sector also multiplies pollutants in the estuary. Based on the above facts, twenty-seven stations (Fig. 1) were selected covering entire estuary from southern (stations 1-10), central (stations 11-15) and northern (16-27) sectors in premonsoon (PRE) and post-monsoon period (POST). During PRE period, the river discharge is minimum and influence of sea water is maximum resulting the estuary to be well mixed creating homogeneity in the water column. Freshwater influence is maximum in monsoon, whereas in POST the river discharge gradually decreases and tidal influence advances and estuary changes to partially mixed type [47].

\subsection{Sampling and analytical methodologies}

Sampling was carried out during the PRE and POST periods of 2016. Surface sediments were collected using Van Veen grab for the analysis of organic biopolymers. The sediments were immediately transferred to plastic containers and transported to laboratory, kept at $4{ }^{\circ} \mathrm{C}$ prior to analysis.

The frozen sediment samples were freeze-dried and homogenised in an agate mortar and kept in a desiccator until analysis. Spectrophotometric methods were employed for determination of biochemical compounds. Protein (PRT) analyses were carried out after extractions with $\mathrm{NaOH}$ $(1 \mathrm{M}, 2 \mathrm{~h})$ and were determined according to the Lowry procedure [40] as modified by Rice [58] accounting for the absorption of phenolic compounds and using albumin as standard. Carbohydrates ( $\mathrm{CHO}$ ) were analysed according to Gerchacov and Hatcher [25] and expressed as glucose equivalents. The method is based on the same principle as the widely used method of Dubois et al. [19], but is specifically adapted for carbohydrate determination in sediments. Lipids (LPD) were extracted by direct elution with chloroform and methanol and assayed using the Barnes and Blackstock [6] procedure using cholesterol as the standard. The biopolymeric (BPC) fraction of the organic carbon was calculated as the sum of PRT, LPD and CHO carbon [21]. To obtain carbon equivalents, each fraction was multiplied by $0.49,0.75$ and $0.4 \mu \mathrm{g}$ of $C \mu \mathrm{g}^{-1}$, respectively [51]. The sum of all PRT, CHO and LPD was defined as the labile or easily assimilated organic fraction $[9,15]$. Total organic carbon (TOC) was analysed using SkalarPrimacs ${ }^{\mathrm{MCS}}$ analyser. Total nitrogen was estimated using Vario EL III CHNS analyser. Acetanilide standards were used to calibrate nitrogen. The complex organic matter (COM) was calculated according to Fichez [23] as the difference between TOC and BPC. The differentiation between fresh and aged organic matter and also to predict the nutritional quality indexes like PRT:CHO and LPD:CHO ratios was employed [9, 15, 29, 30, 33]. The benthic trophic status was elucidated with the threshold values assigned to PRT and CHO by Dell Anno et al. [16]. According to this

(1) Benthic trophic status is hypertrophic $(\mathrm{H})$, if $\mathrm{PRT}>4 \mathrm{mg} / \mathrm{g} ; \mathrm{CHO}>7 \mathrm{mg} / \mathrm{g}$; and $\mathrm{PRT}: \mathrm{CHO}>1$.

(2) Benthic trophic status is eutrophic (E), if PRT $=1.5-$ $4.0 \mathrm{mg} / \mathrm{g} ; \mathrm{CHO}=5-7 \mathrm{mg} / \mathrm{g}$; and PRT:CHO $>1$.

(3) Benthic trophic status is meso-oligotrophic (MO), if $\mathrm{PRT}<1.5 \mathrm{mg} / \mathrm{g} ; \mathrm{CHO}<5 \mathrm{mg} / \mathrm{g} ;$ and $\mathrm{PRT}: \mathrm{CHO}<1$. 
Fig. 1 Location map of sampling sites

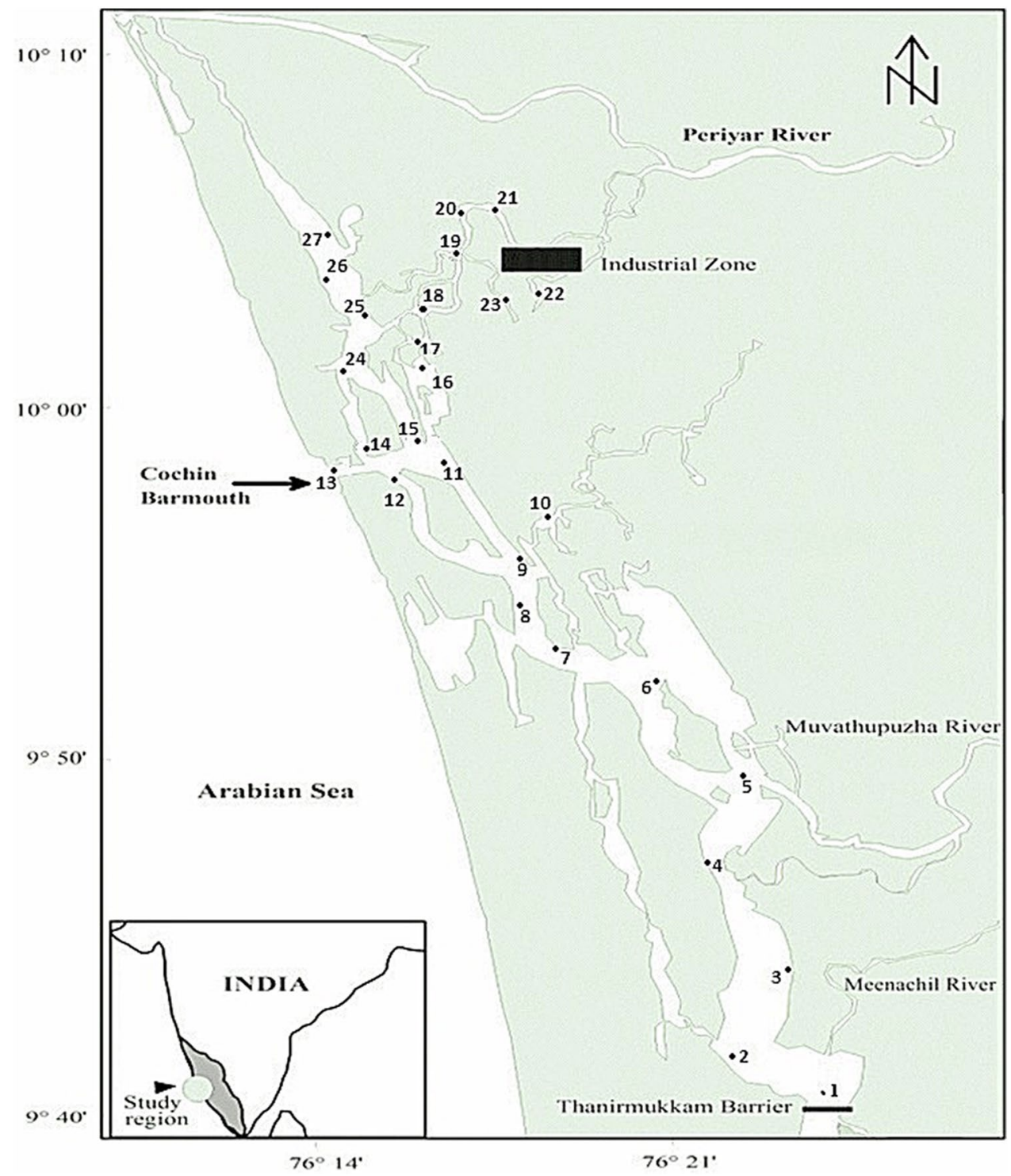

The classification was introduced by Pusceddu et al. [54] as BPC values for ascertaining trophic status were also calculated as
(1) $\mathrm{BPC}>3 \mathrm{mg} / \mathrm{g}$; eutrophic (E)
(2) BPC $1-3 \mathrm{mg} / \mathrm{g}$; mesotrophic (M)
(3) $\mathrm{BPC}<1 \mathrm{mg} / \mathrm{g}$; oligotrophic (O)

To correlate between the variables, statistical analysis using SPSS 13.0 version was used.

\section{Results}

The present paper presents the biochemical data of Cochin estuary comprising the southern, central and northern arms. The study period is divided into two seasons, namely pre-monsoon (PRE) and post-monsoon (POST).

Seasonal variability of biochemical parameters

(1) Pre-monsoon (PRE) 
The labile fraction of organic matter consisting of carbohydrates (CHO), proteins (PRT) and lipids (LPD) in the three zones was found to be fluctuating in nature. The south estuary (SE), where anthropogenic pressures in the form of agricultural practices, sewage and domestic influences, urban development, etc., are evident, showed $\mathrm{CHO}$ concentration ranging from 0.46 to $1.2 \mathrm{mg} / \mathrm{g}$ (0.74 \pm 0.28$)$, PRT from 0.17 to $6.09(1.70 \pm 2.25)$ and LPD from 0.07 to $0.35 \mathrm{mg} / \mathrm{g}(0.19 \pm 0.09)$. The central estuary (CE) where continuous dredging, container terminal activities, transportation channels activities, sewage and domestic inputs are foregoing, the $\mathrm{CHO}$ concentration varies from 0.36 to $1.78 \mathrm{mg} / \mathrm{g}(0.85 \pm 0.57), \mathrm{PRT}$ range from 0.45 to $4.21 \mathrm{mg} / \mathrm{g}(2.33 \pm 1.64)$, and LPD range between 0.09 and $0.31 \mathrm{mg} / \mathrm{g}(0.16 \pm 0.10)$. The northern estuary (NE) includes mainly industrial inputs and effluents, waste outlets with sewage and domestic inputs. Fewer stations are also selected from near-coastal areas where fish peeling centres, fish farming, etc., are undergoing. The $\mathrm{CHO}$ values ranged from 0.15 to $1.07 \mathrm{mg} / \mathrm{g}$ $(0.56 \pm 0.27)$, PRT from 0.65 to $6.51 \mathrm{mg} / \mathrm{g}(2.35 \pm 1.60)$ and LPD from 0.07 to $0.38 \mathrm{mg} / \mathrm{g}(0.15 \pm 0.09)$, respectively. The overall average in Cochin estuary comprising the three zones was found to be $0.67 \pm 0.34 \mathrm{mg} / \mathrm{g}$ for $\mathrm{CHO}$, $2.10 \pm 1.83 \mathrm{mg} / \mathrm{g}$ for PRT and $0.16 \pm 0.08 \mathrm{mg} / \mathrm{g}$ for LPD (Table 1).

\section{(2) Post-monsoon (POST)}

In the estuary with similar conditions and topography as above, the biochemical parameters in the SE ranged from 0.30 to 2.02 with an average value of $1.16 \pm 0.63(\mathrm{CHO})$; 0.16 to $3.40 \mathrm{mg} / \mathrm{g}$ with a mean value of $1.54 \pm 0.95$ (PRT); and 0.38 to $1.73 \mathrm{mg} / \mathrm{g}$ with an average of $1.09 \pm 0.39$ (LPD), respectively. The concentrations in CE ranged from 0.92 to $5.01 \mathrm{mg} / \mathrm{g}$ of $\mathrm{CHO}(2.00 \pm 1.72) ; 0.75$ to $4.07 \mathrm{mg} / \mathrm{g}$ of PRT (2.33 \pm 1.51$)$; and 0.93 to $2.60 \mathrm{mg} / \mathrm{g}$ of LPD $(1.47 \pm 0.67)$. The NE showed values of 0.57 to $5.77 \mathrm{mg} / \mathrm{g}$ with an average

Table 1 Descriptive statistics of biochemical parameters in the PRE $(n=27)$

\begin{tabular}{llcll}
\hline & Minimum & Maximum & Mean & SD \\
\hline CHO $(\mathrm{mg} / \mathrm{g})$ & 0.15 & 1.78 & 0.68 & 0.35 \\
PRT $(\mathrm{mg} / \mathrm{g})$ & 0.17 & 6.51 & 2.10 & 1.83 \\
LPD $(\mathrm{mg} / \mathrm{g})$ & 0.07 & 0.38 & 0.17 & 0.09 \\
BPC $(\mathrm{mg} / \mathrm{g})$ & 0.35 & 3.81 & 1.43 & 0.93 \\
PRT/CHO & 0.25 & 13.17 & 3.94 & 3.57 \\
LPD/CHO & 0.09 & 0.49 & 0.27 & 0.11 \\
TOC (\%) & 0.28 & 6.39 & 2.51 & 1.59 \\
TN (\%) & 0.03 & 0.58 & 0.25 & 0.14 \\
TOC:TN & 5.88 & 12.88 & 9.55 & 1.84 \\
COM (\%) & 0.18 & 6.28 & 2.37 & 1.60 \\
\hline
\end{tabular}

Table 2 Descriptive statistics of biochemical parameters in the $\operatorname{POST}(n=27)$

\begin{tabular}{llcrl}
\hline & Minimum & Maximum & Mean & SD \\
\hline CHO $(\mathrm{mg} / \mathrm{g})$ & 0.3 & 5.77 & 2.00 & 1.56 \\
PRT $(\mathrm{mg} / \mathrm{g})$ & 0.16 & 6.8 & 2.13 & 1.72 \\
LPD $(\mathrm{mg} / \mathrm{g})$ & 0.07 & 3.82 & 1.34 & 0.93 \\
BPC $(\mathrm{mg} / \mathrm{g})$ & 1.35 & 5.83 & 2.86 & 1.20 \\
PRT/CHO & 0.11 & 11.96 & 2.02 & 2.61 \\
LPD/CHO & 0.01 & 4.44 & 1.16 & 1.14 \\
TOC $(\%)$ & 0.23 & 6.24 & 2.44 & 1.63 \\
TN $(\%)$ & 0.03 & 0.55 & 0.23 & 0.14 \\
TOC:TN & 5.36 & 13.4 & 10.10 & 2.13 \\
COM (\%) & 0.1 & 6.01 & 2.16 & 1.61 \\
\hline
\end{tabular}

value of $2.71 \pm 1.79$ for $\mathrm{CHO} ; 0.41$ to $6.80 \mathrm{mg} / \mathrm{g}$ with a mean value of $2.54 \pm 2.21$ for PRT; and 0.07 to $3.82 \mathrm{mg} / \mathrm{g}$ with an average of $1.51 \pm 1.29$ for LPD. The whole average calculated for CHO, PRT and LPD was $2.00 \pm 1.56,2.13 \pm 1.72$ and $1.34 \pm 0.93$ (Table 2).

\section{Discussions}

The predominant labile biopolymer observed during the sampling period was PRT $(71 \%, 38 \%)$ irrespective of the seasons studied, followed by $\mathrm{CHO}(23 \%, 36 \%)$ and LPD (5\%, 24\%). Even though the nature of biochemical composition is diverse in different ecosystems, it is usually characterised by large quantities of PRT followed by carbohydrates with small quantities of $\operatorname{LPD}[20,48,65]$. The dominance of PRT over CHO and LPD reveals the productivity of estuary and better preservation potential of these compounds in sediments as cited previously [50]. Cochin estuary receives surplus amount of allochthonous inputs irrespective of seasons in the form of sewage, domestic effluents, fish waste products all of which contribute to the pool of PRT in the sediment organic matter. Similar suppositions were observed in the estuary $[3,72]$. These enriched PRT contents are readily available and are consumed by microbial process by which the PRT concentration may become low. This might be the probable reason for low PRT content during the POST. The above statement is further supported by PRT:CHO ratios (Fig. 2) affirming the argument that during the PRE season, most of the stations $(n=20)$ were found to exhibit index ratio greater than 1 indicating fresh organic matter and a transformation in POST was noted. About half of the stations were found to have index value less than 1 representing accumulation of aged organic matter. Another possible reason might be due to the increase in concentration of $\mathrm{CHO}$ in the POST. The LPD enhancement in POST is due to 


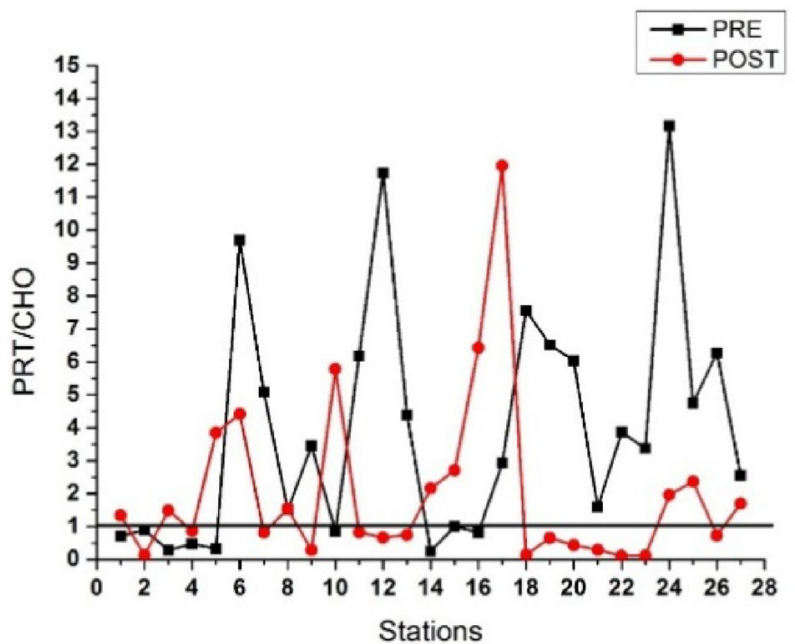

Fig. 2 Seasonal variation of protein-to-carbohydrate ratio

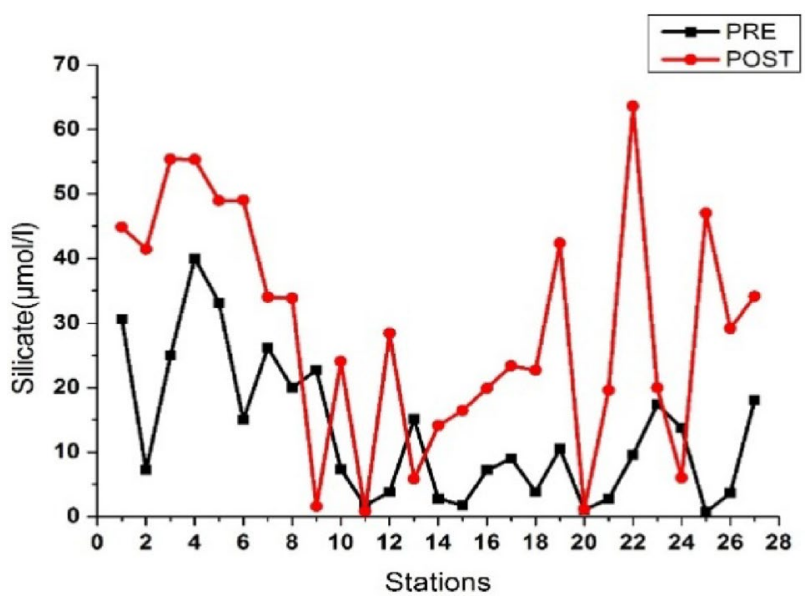

Fig. 3 Seasonal variation of silicate

plankton detritus accumulated in sediments. It is documented that diatoms and faecal pellets of zooplankton are assumed to be important carriers of lipids to marine sediments [4]. Earlier studies have shown that Cochin estuary is diatom-dominated [1]. Profuse concentrations of lipids in post-monsoon in certain stations can be ascertained with anthropogenic sources such as petroleum and sewage inputs. Besides, the silicate concentration was also enhanced during the POST (Fig. 3) which implies that diatoms are abundant, thereby contributing to LPD enhancement. This fact is exemplified as it was observed that the LPD:CHO ratios (Fig. 4) were below 1 (PRE) pointing low quality of organic matter and above 1 (POST) showing the good quality of organic matter.

The total organic carbon (TOC, Fig. 5) content in the estuary was found to vary from 0.28 to $6.39 \%$, with a

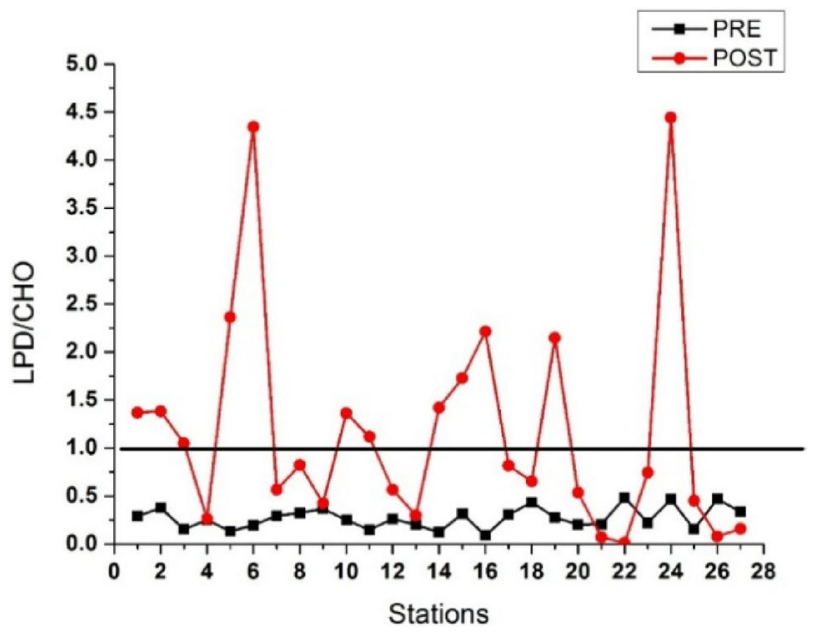

Fig. 4 Seasonal variation of lipid-to-carbohydrate ratio

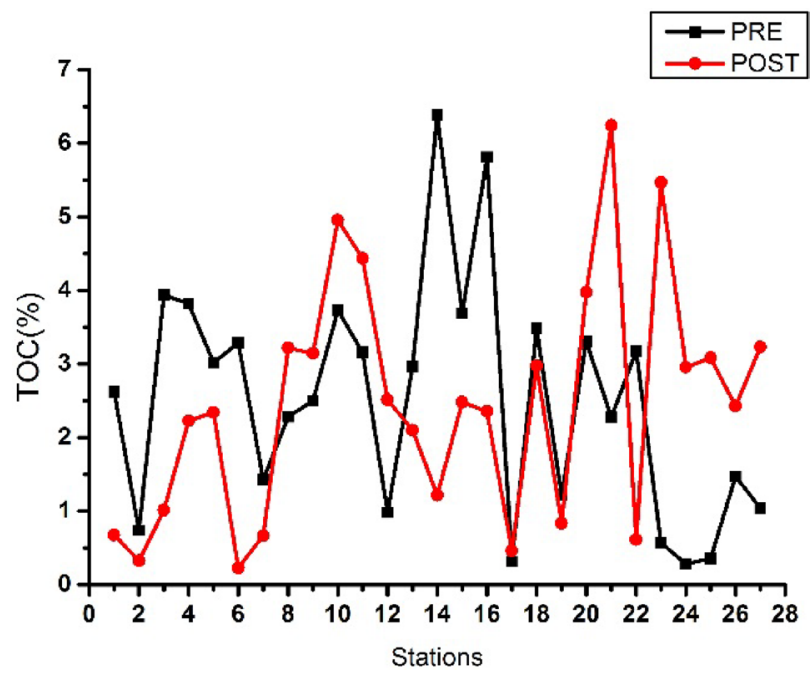

Fig. 5 Seasonal variation of TOC

mean of $2.51 \pm 1.59$ in the PRE, and 0.23 to $6.24 \%$, with a mean of $2.44 \pm 1.63$ in the POST, whereas total nitrogen (TN, Fig. 6) content varies from 0.03 to $0.58 \%(0.25 \pm 0.14$; PRE) and 0.03 to $0.55(0.23 \pm 0.14)$. The plot of TOC with TN (Figs. 7 and 8) in both the seasons showed straight lines with regression coefficient of $R^{2}=0.95$ (PRE) and $R^{2}=0.94$ (POST). Hence, C:N ratios reported here can be approximated to $\mathrm{C}_{\text {org }} / \mathrm{N}_{\text {org }}$. The TOC:TN ratios are widely employed to distinguish between terrestrial and marine organic matter in aquatic ecosystems to portray the source, fate and seasonal processes of organic matter $[66,70,71,80$, 81]. According to Stein [68], TOC:TN values less than 10 point a strict marine origin and values around 10 show both terrestrial and marine organic inputs in sediments. TOC:TN ratios greater than 10 have also been reported for terrestrial organic matter [49]. The TOC:TN ratios (Fig. 9) 


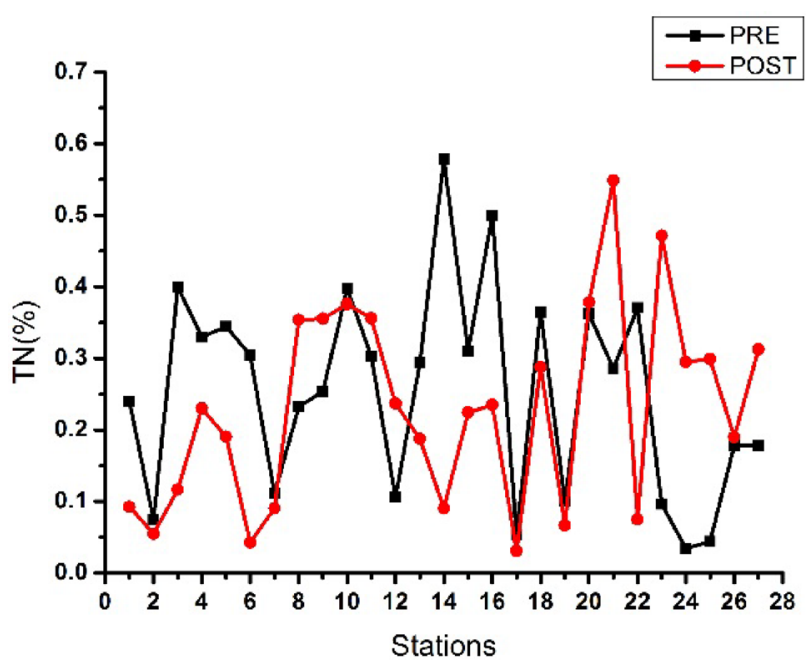

Fig. 6 Seasonal variation of TN

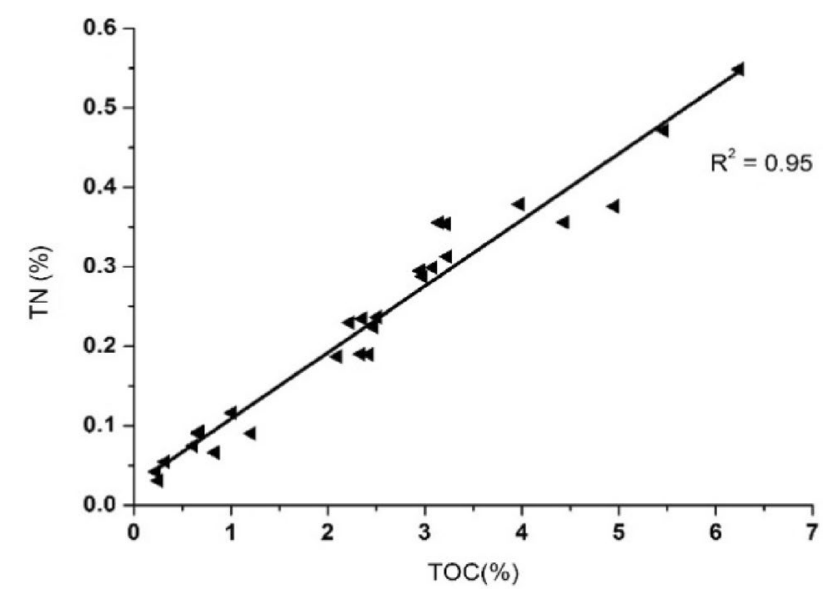

Fig. 7 Correlation of TOC versus TN (PRE)

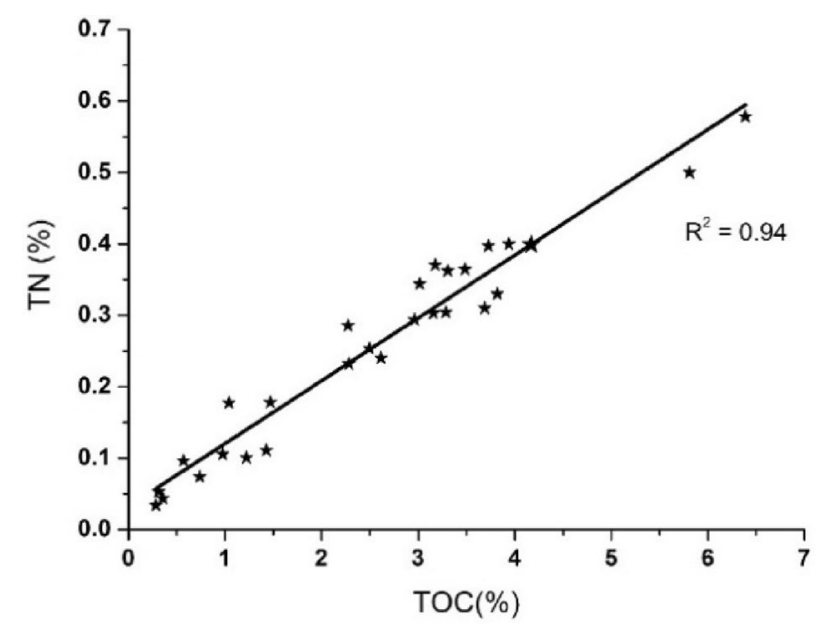

Fig. 8 Correlation of TOC versus TN (POST)

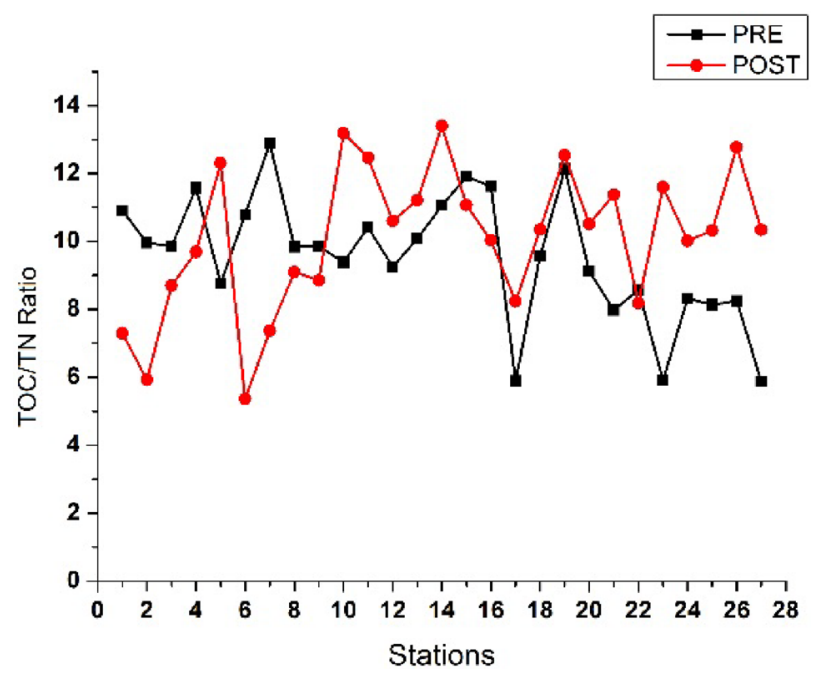

Fig. 9 TOC:TN ratio depicting PRE and POST

during the study varied from 5.88 to 12.88 in the PRE and from 5.36 to 13.40 in the POST. The high PRT concentration during the sampling reveals the presence of nitrogen-enriched organic matter and is subjected to bacterial degradation making the TOC:TN ratios lower. A similar trend was reported for Zuari and Mandovi estuary, generalising the fact that this pattern is common in Indian estuaries along the west coast [5, 22]. Further erstwhile measurements taken in the Cochin estuary (Table 3 ) showed a change in the pattern of TOC:TN ratios reflecting the degradation of organic matter. Besides the estuary being anthropogenic in nature, the inflow of sewage and domestic wastes also contributes to the estuarine organic matter. It is cited previously that sewage inputs generally exhibit TOC:TN ratios around $12[60,77]$ and is adjacent to the mix of terrestrial plants $[18,79]$ and soils. The TOC:TN ratios obtained during the study were close enough to 12 which supports the fact that adequate loads of sewage as well as terrestrial inputs are added to the organic matter. It is attributed that the carbon transported from the rivers into the estuaries may undergo dilution and mineralisation and even mix with marine organic carbon which usually have low TOC:TN ratios which may also lead to lowering of TOC:TN ratios during the study. Similar assumptions have been quoted $[37,69]$. Moreover, nutrient fortification is a frequent syndrome observed in the Cochin estuary [41, 43, 44] which eventually enhances algal population leading to lowering of TOC:TN values $[24,34,56]$. Thus, the organic matter summation in Cochin estuary is profoundly under the influence of amalgamation of marine, terrestrial and sewage inputs.

The biopolymeric carbon (BPC) (Fig. 10) varies in the PRE (range $=0.35-3.81 \mathrm{mg} / \mathrm{g}$; mean $=1.42 \pm 0.92$ ) and POST (range $=1.35-5.83 ;$ mean $=2.86 \pm 1.20$ ). The BPC fraction of 
Table 3 Comparisons of biochemical fractions and TOC:TN ratio within the Cochin estuary

\begin{tabular}{lllll}
\hline CHO $(\mathrm{mg} / \mathrm{g})$ & PRT $(\mathrm{mg} / \mathrm{g})$ & LPD $(\mathrm{mg} / \mathrm{g})$ & TOC:TN ratio & References \\
\hline $0.250-1.229$ & $0.205-1.924$ & $0.312-2.815$ & $4.80-10.62$ & Joseph et al. [35] \\
$1.66-6.339$ & $0.244-2.600$ & $0.415-3.160$ & $0.73-33.62$ & Renjith et al. [57] \\
$0.434-12.839$ & $0.110-19.420$ & $0.115-8.450$ & $0.57-26.75$ & Salas et al. [62] \\
$0.150-5.770$ & $0.170-6.800$ & $0.07-3.820$ & $5.88-13.40$ & Present study \\
\hline
\end{tabular}

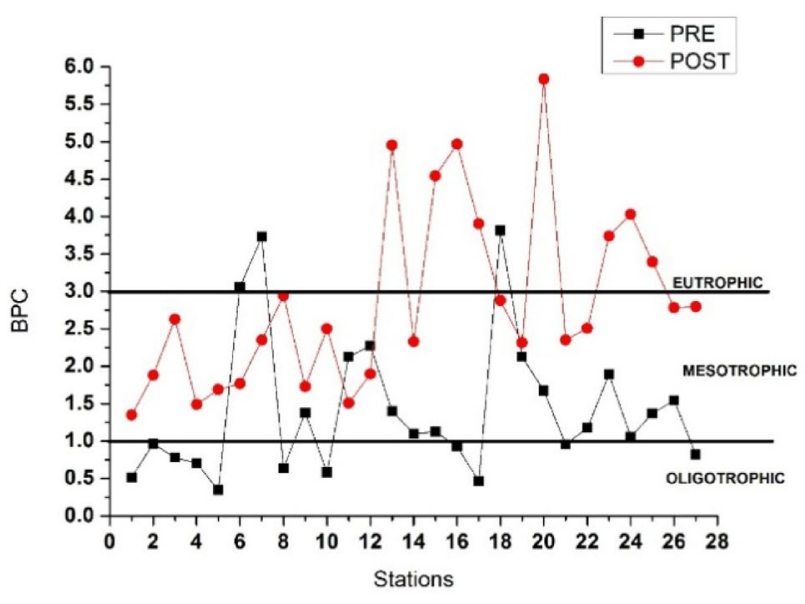

Fig. 10 Distribution of biopolymeric carbon depicting PRE and POST

organic matter is calculated by the sum of PRT, $\mathrm{CHO}$ and LPD and is stated as labile fraction that is readily available to benthic consumers $[53,73]$. The major contributor to the BPC pool was PRT irrespective of seasonal differences. Such high PRT concentration mirrored in the BPC conveys that there is no limitation for heterotrophic metabolism in the estuary. Besides, threshold values of BPC, PRT and $\mathrm{CHO}$ are widely used to predict the benthic trophic status (Table 4). The enhancement of PRT content is features of eutrophic systems [74], and the benthic trophic classification based on PRT unravels the Cochin estuary to be eutrophic in nature. The classification ascertained using BPC unveils mesotrophic condition prevailing in the PRE and peripheral eutrophic system during the POST. The shift in BPC values from PRE to POST corroborates an increase in the labile fraction of organic matter particularly the $\mathrm{CHO}$ and LPD contents. It is cited that when BPC concentrations in the sediment exceed $2.5 \mathrm{mg} \mathrm{C} / \mathrm{g}$, its bioavailable fraction is always less than $10 \%$ [53]. This depicts the fact that during the POST the benthic consumers may experience typically refractory organic carbon. Even though lipid content increases in POST, earlier studies untie the fact that it is largely associated with the refractory fraction of sedimentary organic fraction $[7,33]$. The estuarine and eutrophic environment generally contains BPC equal to $3 \%$ of TOC [20], and during the study, 3.1 and $6.64 \%$ of BPC fractions of the TOC were obtained establishing the fact the estuary can be considered as eutrophic. Such eutrophicated systems have a tendency to accumulate mostly refractory matter [53]. The ratio of BPC to TOC is considered as an indicator of quality of organic matter that is available to its consumers [13]. During the study, low BPC:TOC (Fig. 11) ratios were obtained in both the seasons confirming that a large part organic matter in Cochin estuary is refractory in nature. Complex organic matter (COM)

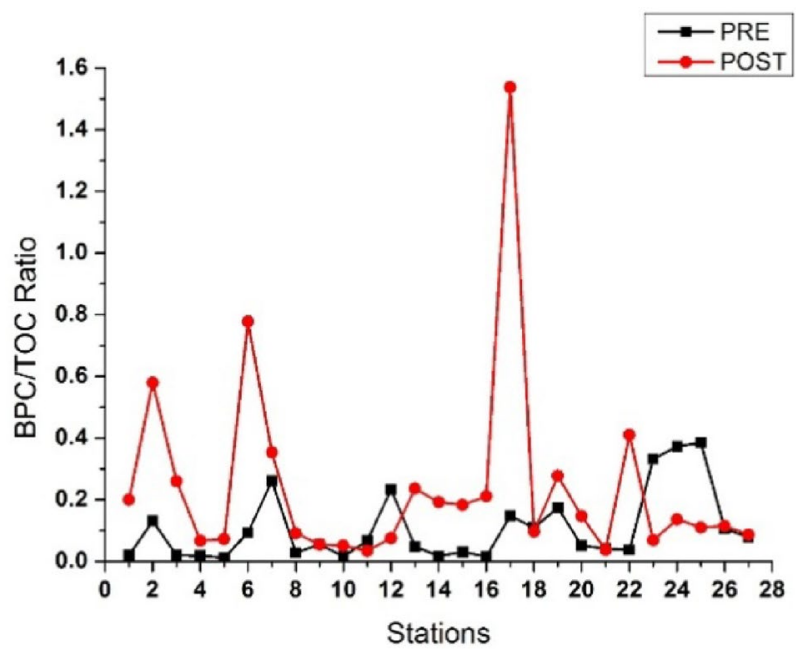

Fig. 11 Seasonal distribution of BPC:TOC ratios
Table 4 Classification of Cochin estuary based on proteins, carbohydrates, biopolymeric carbon and the ratio between protein and carbohydrate (No. of observations $=27$ )

\begin{tabular}{lllll}
\hline Parameter & Season & Classification & Season & Classification \\
\hline & PRE & & POST & \\
BPC & 1.42 & Mesotrophic & 2.95 & Mesotrophic/eutrophic \\
CHO & 0.68 & Meso-oligotrophic & 2 & Meso-oligotrophic \\
PRT & 2.1 & Eutrophic & 2.13 & Eutrophic \\
PRT/CHO & 3.94 & Eutrophic & 2.02 & Eutrophic \\
\hline
\end{tabular}




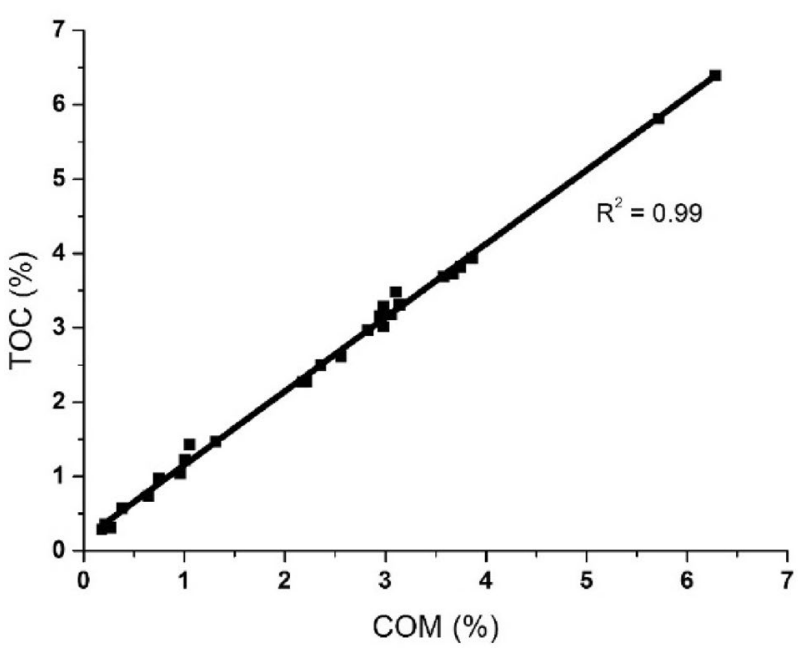

Fig. 12 Correlation between TOC and COM during PRE

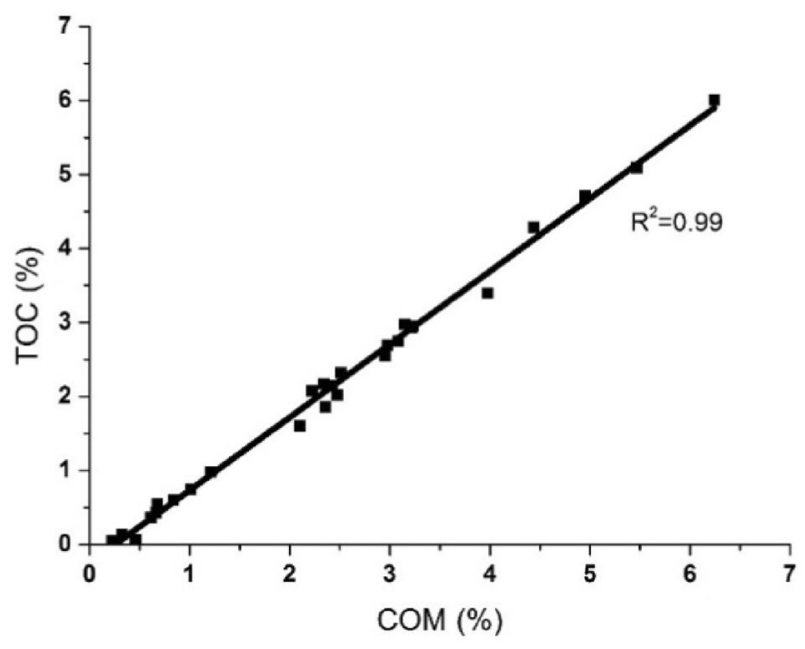

Fig. 13 Correlation between TOC and COM during POST

is the term given to residual fraction of organic matter which is not accounted by the labile fraction and generally consists of complex organic molecules like humic and fulvic acids which are degraded gradually, subjected to burial and lost for benthic food webs [20]. The TOC was positively correlated with COM (Figs. 12 and 13) substantiating the fact that organic matter residing is refractory in character. Further the increase in COM values is in agreement with prior studies [31] stating that decomposition and accumulation of terrigenous material (TOC:TN $>10$ ) can enhance COM concentrations.

The statistical tool, principal component analysis (PCA) (Table 5), was performed on the generated data set comprising both the seasons $(n=54)$. Eigenvalues greater than 1 were taken as the criterion for extraction of the
Table 5 Factor loadings of biochemical components, TOC, TN and COM on four significant principal components for 54 sediment samples. Values above 0.5 are shown

\begin{tabular}{lrcrr}
\hline & PC1 & PC2 & \multicolumn{1}{l}{ PC3 } & \multicolumn{1}{c}{ PC4 } \\
\hline Eigenvalue & 3.655 & 3.303 & 1.828 & 1.213 \\
Variability \% & 33.232 & 30.03 & 16.615 & 11.027 \\
Cumulative \% & 33.232 & 63.262 & 79.877 & 90.904 \\
Factor loadings & & & & \\
CHO & & 0.81 & -0.482 & \\
PRT & & & 0.862 & \\
LPD & & 0.524 & & 0.782 \\
BPC & & 0.906 & & \\
PRT/CHO & & & 0.909 & \\
LPD/CHO & & & & 0.958 \\
TOC & 0.979 & & & \\
TN & 0.939 & & & \\
TOC:TN & 0.646 & & & \\
COM & 0.975 & & & \\
\hline
\end{tabular}

principal components to elucidate the variances found in the data. This analysis transforms the observed variables to new set of variables much smaller in number when compared with the original data. The principal components obtained are arranged in decreasing order of importance for the ease of simplified analysis. The parameter loading for the four components from the principal components is given in Table 4. Liu et al. [38] classified the factor loading as "strong", "moderate" and "weak" based on loading values $>0.75,0.75-0.50$ and $0.50-0.30$, respectively. The positive loading indicates that the contribution of variables increases with the increasing loading in dimension and negative loading indicates a decrease. PC1 accounts for $33.23 \%$ of the total variance in which a strong positive load of TOC, COM and TN was found. This implies that the nature of organic matter lying within the sediments is controlled by the carbon and nitrogen fraction. The ratio of TOC:TN points to combination of marine, sewage and terrestrial inputs; however, a strong positive loading of COM shows that a large part of organic matter is refractory. This points the fact that organic matter present is terrestrial in nature, since terrestrial organic matter contains lignin-rich compound which tend to be more refractory, undergoes less mineralisation and thereby gets preserved in sediment. Similar citations are reported [61]. PC2 accounts for 30.03\% of the total variance of which $\mathrm{CHO}$ were strongly positive loaded. It is established that $\mathrm{CHO}$ are largely produced by autotrophic organisms by photosynthesis; they are well part of aquatic and terrestrial plants, and moreover, microphytobenthos produce large amount of exocellular carbohydrates derived from metabolic activity [75]. Since the vast amount of organic matter in the estuary is found to be 
refractory in nature, it must be concluded that structural carbohydrates are present which is characterised by lower degradation and better conservation in sediments [14]. Besides, the positive loading of $\mathrm{CHO}$ points to the organic detrital nature of the estuary. In such detritus systems, PRT augmentations are correlated with complexion of nitrogen during detritus ageing and also bacterial biomass [20]. This fact is accounted by PC3 in which PRT were strongly positive loaded. The ratio PRT:CHO indicates even though depositions of fresh organic matter is occurring, utilisation of PRT is also taking place simultaneously.

\section{Conclusion}

The spatial and temporal variations observed in the biochemical composition of sediments were primarily associated with the localised anthropogenic influences occurring in the Cochin estuary. The more pronounced labile fraction observed to be linked with anthropogenic pressures was the protein content. The TOC:TN ratios reveal the assemblage of marine, sewage and terrestrial organic matter. Even though the TOC percentage observed was high, the labile fraction available was found to be less as evident from BPC values. This depicts the organic matter in the Cochin estuary to be mostly complex and unaccounted for benthic organisms. The trophic status using BPC unravels the presence of mesotrophic character during the PRE and borderline eutrophic character predominant in the POST. However, the ratio of BPC:TOC was low indicating the nature of organic matter to be refractory and is less available to benthic consumers.

Acknowledgements The authors wish to express thanks to Kerala University of Fisheries and Ocean Studies for providing financial aid for the above study and STIC, Cochin University of Science and Technology, for supporting with chemical analysis.

Funding The project has been undertaken with the financial aid provided by Kerala University of Fisheries and Ocean Studies.

\section{Compliance with ethical standards}

Conflict of interest The authors declare that they have no conflict of interest.

\section{References}

1. Aneeshkumar N, Sujatha $\mathrm{CH}$ (2012) Biomarker pigment signatures in Cochin back water system a tropical estuary south west coast of India. Estuar Coast Shelf Sci 99:182-190

2. Balachandran KK, Raj CML, Nair M, Joseph T, Sheeba P, Venugopal P (2005) Heavy metal accumulation in a flow restricted, tropical estuary. J Earth Syst Sci 65:361-370
3. Balasubramaniam S, Charles J, Jeeva Ashaletha S (2012) Adoption of quality management practice in seafood processing sector in Cochin region. Fish Technol 49(1):72-79

4. Baldi F, Marchetto D, Pini F, Fani R, Michaud L, Giudice AL, Berto D, Giani M (2010) Biochemical and microbial features of shallow marine sediments along the Terra Nova Bay (Ross Sea, Antartica). Cont Shelf Res 30:1614-1625

5. Bardhan P, Karapukar SG, Shenoy DM, Kurian S, Sarkar A, Maya MV, Naik H, Varik S, Naqui SWA (2015) Carbon and nitrogen isotopic composition of suspended particulate organic matter in Zuari Estuary, west Coast of India. J Mar Syst 141:90-97

6. Barnes H, Blackstock J (1973) Estimation of lipids in marine animals tissues: detailed investigation of the sulphophosphovanillin method for "total" lipids. J Exp Mar Biol Ecol 12:103-118

7. Cartes JE, Gremare A, Maynou F, Villora-Moreno S, Dinet A (2002) Bathymetric changes in the distributions of particulate organic matter and associated fauna along a deep-sea transect down the Catalan sea slope (North western Mediterranean). Prog Oceanogr 53:29-56

8. Cifuentes LA (1991) Spatial and temporal variations in terrestrially derived organic matter from sediments of the Delaware estuary. Estuaries 14(4):414-419

9. Cividanes S, Incera M, Lo'pez J (2002) Temporal variability in the biochemical composition of sedimentary organic matter in an intertidal flat of the Galician coast (NW Spain). Oceanol Acta 25:1-12

10. Colombo JC, Silverberg N, Gearing JN (1996) Biochemistry of organic matter in the Laurentian Trough, II. Bulk composition of the sediments and relative reactivity of major components during early diagenesis. Mar Chem 51:295-314

11. Cotano U, Villate $F(2006)$ Anthropogenic influence on the organic fraction of sediments in two contrasting estuaries: a biochemical approach. Mar Pollut Bull 52:404-414

12. Danovaro R, Fabiano M (1996) Detritus-bacteria-meiofauna interactions in a seagrass bed (Posidoniaoceanica) of the NW Mediterranean. Mar Biol 127:1-13

13. Danovaro R, Fabiano M (1997) Seasonal changes in quality and quantity of food available forbenthic suspension-feeders in the Golfo Marconi (North-Western Mediterranean). Estuar Coast Shelf Sci 44:726-733

14. Danovaro R, Marrale D, Della Croce N, Parodi P, Fabiano M (1999) Biochemical composition of sedimentary organic matter and bacterial distribution in the Aegean Sea: trophic state and pelagic-benthic coupling. J Sea Res 42:117-129

15. Danovaro R, Fabiano M, Della Croce N (1993) Labile organic matter and microbial biomass in deep-sea sediments (Eastern Mediterranean Sea). Deep-Sea Res 40:953-965

16. Dell Anno A, Mei ML, Pusceddu A, Danovaro R (2002) Assessing the trophic state and eutrophication of coastal marine systems. A new approach based on the biochemical composition of sediment organic matter. Mar Pollut 44:611-622

17. Dell'Anno A, Fabiano M, Mei ML, Danovaro R (2000) Enzymatically hydrolysed protein and carbohydrate pools in deep-sea sediments: estimates of the bioavailable fraction and methodological considerations. Mar Ecol Prog Ser 196:15-23

18. Devesa-Rey R, Barral MT (2012) Allochthonous versus autochthonous naturally occurring organic matter in the Anll'ons river bed sediments (Spain). Environ Earth Sci 66:773-782

19. Dubois M, Gilles KA, Hamilton SK, Rebers PA (1956) Colorimetric method for determination of sugars and related substances. Anal Chem 28:350-356

20. Fabiano M, Danovaro R (1994) Composition of organic matter in sediments facing a river estuary(Tyrrhenian Sea): relationship with bacteria and microphytobenthic biomass. Hydrobiologia 277:71-84 
21. Fabiano M, Danovaro R, Fraschetti S (1995) A three year time series of elemental and biochemical composition of organic matter in subtidal sandy sediments of the Ligurian sea (North western Mediterranean). Cont Shelf Res 15:1453-1469

22. Fernandes $L$ (2011) Origin and biochemical cycling of particulate nitrogen in the Mandovi estuary. Estuar Coast Shelf Sci 94(3):291-298

23. Fichez R (1991) Composition and fate of organic matter in submarine cave sediments; implications for the biogeochemical cycle of organic carbon. Oceanol Acta 14:369-377

24. Gao X, Yang Y, Wang C (2012) Geochemistry of organic carbon and nitrogen in surface sediments of coastal Bohai bay inferred from their ratios and stable isotopic signatures. Mar Pollut Bull 64:1148-1155

25. Gerchacov SM, Hatcher PG (1972) Improved technique for analysis of carbohydrates in the sediment. Limnol Oceanogr 17:938-943

26. Gireeshkumar TR, Deepulal PM, Chandramohanakumar N (2012) Distribution and sources of sedimentary organic matter in a tropical estuary, south west coast of India (Cochin estuary): a baseline study. Mar Pollut Bull 66:239-245

27. Gopalan UK, Vengayil DT, Udaya VP, Krishnankutty M (1983) The shrinking backwaters of Kerala. J Mar Biol Assoc India 25:131-141

28. Graham MC, Eaves MA, Framer JG, Dobson J, Fallick AE (2001) A study of carbon and nitrogen stable isotope and elemental ratios as potential indicators of source and fate of organic matter in sediments of the forth estuary, Scotland. Estuar Coast Shelf Sci 52:375-380

29. Gremare A, Amoroux JM, Charles F, Dinet A, Riaux-Gobin C, Baudart J, Mederach L, Bodiou JY, Vertion G, Colomines JC, Albert $P$ (1997) Temporal changes in the biochemical composition and nutritive value of the particulate organic matter available to surface deposit-feeders: a two years study. Mar Biol Prog 150:195-296

30. Gremare A, Medernach L, de Bovee F, Amoroux JM, Vetion G, Albert $P$ (2002) Relationship between sedimentary organics and benthic meiofauna on the continental shelf and upper slope of the Gulf of Lions (NW Mediterranean). Mar Ecol Prog Ser 234:85-94

31. Hargrave BT, Phillips GA, Doucette LI, White MJ, Milligan TG, Wildish DJ, Cranston RE (1995) Biochemical observations to assess benthic impacts of organic enrichment from marine aquaculture in the western isles region of the bay of Fundy, 1994. Canadian Technical report of fisheries and aquatic science, 2062

32. Hu J, Peng P, Jia G, Mai B, Zhang G (2006) Distribution and sources of organic carbon, nitrogen and their isotopes in sediments of the subtropical Pearl river estuary and adjacent shelf, South China. Mar Chem 98:274-285

33. Isla E, Gerdes D, Palanques A, Gili JM, Arntz W (2006) Biochemical composition of marine sediment from the eastern Weddel sea. J Mar Syst 60:255-267

34. Jia J, Gao JH, Li YF, Yang Y (2012) Environmental changes in Shamei Lagoon, Hainan island, China: interactions between natural processes and human activities. J Asian Earth Sci 52:158-168

35. Joseph MM, Kumar CRS, Kumar TGR, Renjith KR, Chandramohanakumar N (2008) Biogeochemistry of surficial sediments in the intertidal systems of a tropical environment. Chem Ecol 24:247-258

36. Joy CM, Balakrishnan KP, Joseph A (1990) Effect of industrial discharges on the ecology of phytoplankton production in the river Periyar (India). Water Res 24(6):787-796

37. Lansard B, Rabouille C, Denis L, Grenz C (2009) Benthic remineralization at the land-ocean interface: a case study of the
Rhone river (NW Mediterranean sea). Estuar Coast Shelf Sci 81(4):544-554

38. Liu CW, Lin Kao- Hung, Kuo Yi-Ming (2003) Application of factor analysis in the assessment of ground water quality in a black foot disease area in Taiwan. Sci Total Environ 313:77-89

39. Liu SM, Li XN, Zhang J, Wei H (2007) Nutrient dynamics in Jiaozhou Bay. Water Air Soil Pollut Focus 7:625-643

40. Lowry $\mathrm{OH}$, Rosebrough NJ (1951) Protein measurement with the Folin phenol reagent. J Biol Chem 193:265-275

41. Martin GD, Vijay VJ, Laluraj CM, Madhu NV, Joseph T, Nair M et al (2008) Fresh water influence on nutrient stoichiometry in a tropical estuary, South west coast of India. Appl Ecol Environ Res 6(1):57-64

42. Martin GD, Muraleedharan KR, Vijay JG, Rejomon G, Madhu NV, Shivaprasad A et al (2010) Formation of anoxia and denitrification in the bottom waters of a tropical estuary, southwest coast of India. Biogeosci Discus 7:1751-1782

43. Martin GD, Nisha PA, Balachandran KK, Madhu NV, Nair M, Shaiju $P$ et al (2011) Eutrophication induced changes in benthic community structure of a flow restricted tropical estuary (Cochin backwaters), India. Environ Monit Assess 176:427-438

44. Martin GD, Jyothibabu R, Madhu NV, Balachandran KK, Nair Maheswari, Muraleedharan KR, Arun PK, Haridevi CK, Revichandran C (2013) Impact of eutrophication on the occurrence of Trichodesmium in the Cochin backwaters, the largest estuary along the west coast of India. Environ Monit Assess 185(2):1237-1253

45. Mayer LM, Macko SA, Cammen L (1988) Provenance, concentrations and nature of sedimentary organic nitrogen in the Gulf of Maine. Mar Chem 25:291-304

46. Mayer L, Schick L, Sawyer L, Plante C, Jumars PA, Self RL (1995) Bioavailable aminoacid in sediments: a biomimetic, kinetic based approach. Limnol Oceanogr 40:511-520

47. Menon NN, Balchand AN, Menon NR (2000) Hydrobiology of the Cochin backwater system-a review. Hydrobiologia 430(1-3):149-183

48. Meyer-Reil LA (1983) Benthic response to sedimentation events during autumn to spring at ashallow water station in the Western Kiel Bight. II. Analysis of benthic bacterial populations. Mar Biol 77:247-256

49. Meyers PA, Ishiwatari R (1993) Lacustrine organic chemistry-an overview of indicators of organic matter sources and diagenesis in lake sediments. Org Geochem 20(7):867-900

50. Nguyen R, Harvey HR (2001) Preservation of protein in marine systems: Hydrophobic and other noncovalent associations as major stabilizing forces. Geochim Cosmochim Acta 65:1467-1480

51. Pusceddu A, Dell Anno A, Fabiano M (2000) Organic matter composition in coastal sediments at Terra Nova Bay (Ross Sea) during summer 1995. Polar Biol 23:288-293

52. Pusceddu A, Dell'Anno A, Danovaro R, Manini E, Sara G, Fabiano M (2003) Enzymatically hydrolysable protein and carbohydrate sedimentary pools as indicators of the tropic state of detritus sink systems: a case study in the Mediterranean coastal lagoon. Estuaries 26:641-650

53. Pusceddu A, Dell'Anno A, Fabiano M, Danovaro R (2009) Quantity and bioavailability of sediment organic matter as signatures of benthic tropic status. Mar Ecol Prog Ser 375:41-52

54. Pusceddu A, Bianchelli S, Gambi C, Danovaro R (2011) Assessment of benthic tropic status ofmarine coastal ecosystems: significance of meiofaunal rare taxa. Estuar Coast Shelf Sci 93(4):420-430

55. Quasim SZ (2003) Cochin estuary and Vembanad lake. Indian estuaries. Allied Publishers Pvt Ltd, Mumbai. ISBN: 81-7764-369-X 
56. Ranjan RK, Routh J, Ramanathan AL (2010) Bulk organic matter characteristics in the Pichavaram mangrove-estuarine complex, South-eastern India. Appl Geochem 25:1176-1186

57. Renjith KR, Joseph MM, Ghosh PK, Rahman H, Kumar CRS, Chandramohanakumar N (2012) Biogeochemical facsimile of the organic matter quality and trophic status of a micro-tidal tropical estuary. Environ Earth Sci https://doi.org/10.1007/s1266 5-012-2159-0

58. Rice DL (1982) The detritus nitrogen problem: new observations and perspectives from organic geochemistry. Mar Ecol Prog Ser 9:153-162

59. Rossi F, Como S, Cort S, Lardicci C (2001) Seasonal variation of a deposit-feeders assemblage and sedimentary organic matter in a brackish basin mudflat (Western Mediterranean, Italy). Estuar Coast Shelf Sci 53:181-191

60. Ruiz-Fernandez AC, Hillaire-Marcel C, Ghaleb B, Soto-Jimenez M, Paez-Osuna F (2002) Recent sedimentary history of anthropogenic impacts on the Culiacan river estuary Northwestern Mexico: geochemical evidence from organic matter and nutrients. Environ Pollut 118:365-377

61. Rullkotter J (2006) Organic matter: the driving force for early diagenesis. In: Schulz HD, Zabel M (eds) Marine geochemistry. Springer

62. Salas PM, Sujatha CH, Kumar CRS (2015) Fate and source distribution of organic constituents in a river-dominated tropical estuary. J Earth Syst Sci 124(6):1265-1279

63. Sankaranarayanan VN, Panampunnayil SU (1979) Studies on the organic carbon, nitrogen and phosphorous in the sediments of cochin back waters. Indian J Mar Sci 8:141-145

64. Saraladevi K (1986) Effect of industrial pollution on the benthic communities of the estuary. Ph.D thesies, University of Science and Technology Cochin, $\mathrm{p} 380$

65. Sargent JR, Hopkins CCE, Seiring JV, Youngson A (1983) Partial characterization of organic material in surface sediments from Balsfjorden, northern Norway in relation to its origin and nutritional value for sediment-ingesting animals. Mar Biol 76:87-94

66. Schmidt F, Hinrichs KU, Elvert M (2010) Sources, transport and partitioning of organic matter at a highly dynamic continental margin. Mar Chem 118:35-37

67. Srinivas K, Revichandran C, Maheswaran PA, Ashraf TTM, Murukesh N (2003) Propagation of tides in the cochin estuarine system, southwest coast of India. Indian J Mar Sci 32(1):14-24

68. Stein R (1991) Accumulation of organic carbon in Baffin Bay and Labrador Sea sediments (ODP-Leg 105). In: Accumulation of organic carbon in marine sediments. Lecture notes in earth sciences, vol 34. Springer, Berlin, pp 40-84

69. Tesi T, Miserocchi S, Goni MA, Langone L, Boldrin A, Turchetto $M$ (2007) Organic matter origin and distribution in suspended particulate materials and surficial sediments from the Western Adriatic sea (Italy). Estuar Coast Shelf Sci 73:431-446

70. Tyson RV (ed) (1995) Abundance of organic matter in sediments: TOC, hydrodynamic equivalence, dilution and flux effects. In: Sedimentary organic matter. Springer, Dordrecht, pp 81-118

71. Usui T, Nagao S, Yamamoto M et al (2006) Distribution of sources of organic matter in surficial sediments on the shelf and slope of Tokachi, Western North Pacific, Inferred from C and N stable isotopes and C/N ratios. Mar Chem 98:241-259

72. Vasudevan PN (2000) Biogeoorganics in the sedimentary environmental of Cochin estuary. PhD Thesis, Cochin University of Science and Technology, India

73. Venturini N, Pita AL, Brugnoli E, Garcia-Rodriguez F, Burone L, Kandratavicius N, Hutton M et al (2012) Benthic tropic status of sediments in a metropolitan area (Rio de la Plata estuary): linkages with natural and human pressures. Estuar Coast Shelf Sci 112:139-152

74. Vezzulli Luigi, Fabiano Mauro (2006) Sediment biochemical and microbial variables for the evaluation of trophic status along the Italian and Albanian continental shelves. J Mar Biol Assoc U K 86:27-37

75. Welker C, Sdrigotti E, Covelli S, Faganeli J (2002) Microphytobenthos in the Gulf of Trieste (Northern Adriatic Sea): relationship with Labile sedimentary organic matter and nutrients. Estuar Coast Shelf Sci 55(2):259-273

76. Wu Y, Bao H, Unger D, Herbeck LS, Zhu Z, Zhang J, Jennerjahn TC (2013) Biogeochemical behaviour of organic carbon in a small tropical river and estuary, Hainan, China. Cont Shelf Res 57:32-43

77. Xiao HY, Liu CQ (2010) Identifying organic matter provenance in sediments using isotopic ratios in an urban river. Geochem J 44:181-187

78. Yamamuro $M(2000)$ Chemical tracers of sediment organic matter origins in two coastal lagoons. J Mar Syst 26:127-134

79. Yamamuro M, Kamia H (2014) Elemental (C, N, P) and isotopic $\left({ }^{13} \mathrm{C},{ }^{15} \mathrm{~N}\right)$ signature of primary producers and their contribution to the organic matter in coastal lagoon sediment. Landsc Ecol Eng 10(1):65-75

80. Zhang S, Peng P, Huang W et al (2009) PCDD/PCDF pollution in soils and sediments from the Pearl river delta of China. Chemosphere 75:1186-1195

81. Zhang SR, Lu XX, Sun HG et al (2009) Geochemical characteristics and fluxes of organic carbon in a human disturbed mountainous river (Luodingjiang river) of the Zhujiang (Pearl river), China. Sci Total Environ 407:815-825 